\title{
GLOSA DO WYROKU SĄDU APELACYJNEGO W LODZI Z DNIA 14 CZERWCA 2018 R., II AKA 111/18
}

\begin{abstract}
Streszczenie. Artykuł stanowi krytyczną glosę do wyroku Sądu Apelacyjnego w Łodzi z dnia 14 czerwca 2018 r., II AKa 111/18. Autorzy, dostrzegając złożoną problematykę zagadnienia broni palnej zarówno na gruncie prawa karnego, jak i na płaszczyźnie doktryny kryminalistycznej, podjęli w glosie próbę dookreślenia przesłanek kwalifikacji broni palnej i urządzeń strzelających, takich jak rewolwer Zoraki. Niewątpliwie omawiane rewolwery spełniają część kryteriów z definicji broni palnej z art. 7 u.b.a., bowiem stanowią przenośną broń lufową, która miota i została przeznaczona do miotania pocisków, jednak biorąc za punkt wyjścia wykładnię treściową tegoż artykułu, konieczne jest jeszcze określenie, czy wykorzystana w mechanizmie wystrzału substancja jest „materiałem miotającym”, czego sąd nie uczynił. Pojęcie to Autorzy precyzują poprzez wykluczenie zastosowania potocznego rozumienia tego sformułowania i odwołanie się do języka specjalistycznego określonego w normie obronnej, zawierającej definicje zakresowe materiałów wybuchowych. W glosie poruszona jest także kwestia znamienia „niebezpieczeństwa” broni palnej i problemów interpretacyjnych na gruncie wykładni treściowej i systemowej art. 7 ust. 1 u.b.a., art. 263 i art. $280 \S 2$ k.k. Autorzy argumentują w ten sposób stanowisko, że obecne brzmienie art. 7 ust. 1 u.b.a. nie umożliwia samodzielnej, pełnej rekonstrukcji wszystkich istotnych znamion do przyjęcia odpowiedzialności karnej. Glosa wyraża także postulaty de lege ferenda odnośnie zmiany brzmienia art. 7 ust. 1 u.b.a. i wprowadzenia kryterium energetycznego dla broni palnej oraz dookreślenia przesłanki „materiału miotającego” poprzez stwierdzenie, iż jest to materiał wybuchowy albo materiał miotający lub inicjujący, co pozwoliłoby na precyzyjną ocenę co do kwalifikacji prawnej penalizowanych zachowań.
\end{abstract}

Słowa kluczowe: broń palna, Keseru, Zoraki, przesłanka niebezpieczeństwa, definicja broni, materiał wybuchowy, materiał miotający, materiał inicjujący, odpowiedzialność karna.

Cechy i konstrukcja takiej broni, jak rewolwer Zoraki dowodzą, że przedmiot ten stanowi niebezpieczne dla życia lub zdrowia urządzenie, które na skutek spalenia materiału miotającego jest zdolne do wystrzelenia pocisku z lufy,

* Uniwersytet Łódzki, Wydział Prawa i Administracji, Katedra Postępowania Karnego i Kryminalistyki, p.grzegorczyk.wpia@gmail.com.

** Uniwersytet Łódzki, Wydział Prawa i Administracji, Katedra Postępowania Karnego i Kryminalistyki, zbigniew.wardak@gmail.com. 
a przez to rażenia celów na odległość. Broń palna zdefiniowana została jako „przenośna broń lufowa” (art. 7 ust. 1 ustawy z dnia 21 maja 1999 r. o broni i amunicji (t.j. Dz.U. z 2020 r. poz. 955 ze zm., dalej: u.b.a.). To właśnie użycie określenia „broń” wskazuje na pewien minimalny stopień niebezpieczności, którym powinien charakteryzować się przedmiot, aby mógł zostać uznany za broń palną. „Broń” jest w języku polskim definiowana jako narzędzie walki, przedmiot służący do obrony własnej lub do atakowania nieprzyjaciela, oręż. W tym określeniu zawarty jest wymóg wskazanego poziomu niebezpieczności dla życia lub zdrowia. Cechę niebezpieczności broni palnej należy wyprowadzić także z treści przepisów części szczególnej ustawy z dnia 6 czerwca 1997 r. Kodeks karny (t.j. Dz.U. z 2020 r. poz. 1444 ze zm., dalej: k.k.). W tych bowiem typach przestępstw, gdzie broń palna stanowi narzędzie przestępstwa występuje zwrot „broń palna, nóż lub inny podobnie niebezpieczny przedmiot" (jak w art. 280 § 2 k.k.). Te zasadnicze właściwości broni palnej, obok noża, stanowią również kryterium oceny niebezpieczności innych przedmiotów, przy czym chodzi o „niebezpieczność” ujmowaną in abstracto.

Punktem wyjścia do dalszych rozważań jest odpowiedź na pytanie czy rewolwery takie jak Zoraki i inne jemu podobne ${ }^{1}$ wypełniają definicję treściową broni palnej z art. 7 u.b.a., zgodnie z którym w rozumieniu ustawy bronią palną jest każda przenośna broń lufowa, która miota, jest przeznaczona do miotania lub może być przystosowana do miotania jednego lub większej liczby pocisków lub substancji w wyniku działania materiału miotającego ${ }^{2}$. Mają one konstrukcję

${ }^{1}$ Np. Keseru K-10, Zoraki R-1 K-10, Ekol Viper R1 K10, Major Eagle, Shotgum.

${ }^{2}$ Definicja ta obowiązuje od 10 marca 2011 roku i została dokonana ustawą z dnia 5 stycznia $2011 \mathrm{r}$. o zmianie ustawy o broni i amunicji oraz ustawy o wykonywaniu działalności gospodarczej w zakresie wytwarzania i obrotu materiałami wybuchowymi, bronią, amunicją oraz wyrobami i technologią o przeznaczeniu wojskowym lub policyjnym (Dz.U. nr 38, poz. 195 z późn. zm.). W poprzedniej definicji wskazywano, iż broń palna jest to niebezpieczne dla życia lub zdrowia urządzenie, które w wyniku działania sprężonych gazów, powstających na skutek spalania materiału miotającego, jest zdolne do wystrzelenia pocisku lub substancji z lufy albo elementu zastępującego lufę, a przez to do rażenia celów na odległość, z zastrzeżeniem ust. 2. Ten ostatni przepis zawierał (i zawiera nadal w niezmienionej postaci) definicję broni palnej sygnałowej. Uzupełnieniem tej definicji jest przepis art. 7 ust. 1a u.b.a., zgodnie z którym w rozumieniu ustawy za dający się przystosować do miotania jednego lub większej liczby pocisków lub substancji w wyniku działania materiału miotającego uznaje się przedmiot, który ze względu na swoją budowę lub materiał, z którego jest wykonany, może być łatwo przerobiony w celu miotania (odnośnie nowej definicji zob. szerzej w szczególności Herzog 2011, 64-82; Kasprzak 2013a; Stępka, Kwiatkowska-Wójcikiewicz 2013, 37-52; Grzegorczyk, Wardak 2017a, 85-99; Rejmaniak 2018, 78-103). Dodatkowo w art. 5 ust. 1 u.b.a. wskazano, że gotowe lub obrobione istotne części broni lub amunicji uważa się za broń lub amunicję. Takimi istotnymi częściami na podstawie art, 5 ust, 2 u.b.a. są: szkielet broni, baskila, lufa z komorą nabojową, zamek, komora zamkowa oraz bęben nabojowy (odnośnie istotnych części broni zob. szerzej w szczególności: Kulicki, Stępka 2009, 509-517; Kasprzak 2010, 121-128; Rejmaniak 2017, 61-69; Wardak 2017, 126-137). 
rewolwerów, przy czym w bębnie nabojowym znajdują się dwie mniejsze komory, połączone kanałem ogniowym. Do bębna nabojowego od strony rękojeści możliwe jest załadowanie nabojów alarmowych bocznego zapłonu systemu Floberta kal. $6 \mathrm{~mm}$ short, zaś do komory od strony lufy, w zależności od typu rewolwerów, wprowadza się pociski gumowe bądź kompozytowe (gumowo-metalowe) kal. $10 \mathrm{~mm}^{3}$ albo śrut kal. $4,5 \mathrm{~mm}^{4}$, albo kal. $5,5 \mathrm{~mm}^{5}$. W przypadku rewolwerów kal. $10 \mathrm{~mm}$ lufa jest gładka, natomiast w przypadku rewolwerów na śrut kal. 4,5 mm bądź 5,5 mm lufa jest gwintowana. Strzelanie jest możliwe w systemie Single Action, tzn. poprzez nacisk na język spustowy po odciągnięciu kurka oraz w Double Action, tj. bez konieczności naciągnięcia kurka następuje obrót bębna nabojowego i uderzenie w nabój alarmowy. Podczas odpalania naboju alarmowego powstają gazy. Ciśnienie wydzielających się gazów powoduje wystrzelenie z lufy rewolweru pocisku (Bogusz et al. 2011, 33-34; Ćwik, Juszczyk 2013, 54-55; Kuliczkowski, Juszczyk 2015, 21-22; Borusiński, Juszczyk 2018, 10-11).

W glosowanym wyroku ${ }^{6}$ Sąd przyjął, że cechy i konstrukcja takiej broni, jak rewolwer Zoraki dowodzą, że przedmiot ten stanowi niebezpieczne dla życia lub zdrowia urządzenie, które na skutek spalenia materiału miotającego jest zdolne do wystrzelenia pocisku z lufy, a przez to rażenia celów na odległość. Odnośnie kwalifikacji prawnej rewolwerów podobnej konstrukcji, takich jak w szczególności Zoraki, z jednej strony wskazuje się, że konstrukcja tych rewolwerów umożliwia wystrzeliwanie kulistych pocisków gumowych przy wykorzystaniu ciśnienia gazów powstających podczas spalania się materiału miotającego, którym jest materiał wybuchowy inicjujący, zawarty w nabojach alarmowych bocznego zapłonu kal. $6 \mathrm{~mm}$ wz. Flobert. Powoduje to, że w świetle ustawy o broni i amunicji rewolwery hukowo-kinetyczne kal. $6 \mathrm{~mm} / 10 \mathrm{~mm}$ spełniają wymogi definicji broni palnej, na posiadanie których wymagane jest pozwolenie (Ćwik, Juszczyk 2013, 56; Borusiński, Juszczyk 2018, 11). Podnosi się także, że taki rewolwer nie spełnia kryteriów zawartych w definicji treściowej broni alarmowej, gdyż wystrzeliwuje pociski na odległość większą, niż 1 metr, ale jest bronią palną rozdzielnego ładowania (Kulicki, Stępka 2012, 443-444), której zasada działania w pełni odpowiada działaniu broni palnej, a zatem w pełni odpowiadają definicji broni palnej z art. 7 ust. 1 u.b.a. (Kasprzak 2013b, 75-76). W orzecznictwie m.in. Sąd Najwyższy w wyroku z dnia 30 czerwca 2016 r., sygn. akt II KK 47/16 zajmował się stroną podmiotową w przypadku posiadania rewolweru Shotgum.

${ }^{3}$ Np. Keseru K-10, Zoraki R-1 K-10.

${ }^{4} \mathrm{~Np}$. Keseru K-45, Zoraki R-1 K-45.

${ }^{5} \mathrm{~Np}$. Keseru K-55, Zoraki R-1 K-55.

${ }^{6}$ Orzecznictwo Sadu Apelacyjnego w Lodzi 2018: 2, poz. 87; Prokuratura i Prawo 2019: 2, poz. 29; Krakowskie Zeszyty Sąowe 2019: 1, poz. 39; Lex nr 2601849; Legalis nr 1861332.

${ }^{7}$ OSNPK 2016: 10, poz. 5; Krakowskie Zeszyty Sadowe 2016: 10, poz. 17; Prokuratura i Prawo - dodatek Orzecznictwo 2016: 10, poz. 5; Lex 2077541; Legalis 1482667; z glosą częściowo krytyczną: Grzegorczyk, Wardak (2017b, 85-99). 
Niewątpliwie omawiane rewolwery spełniają część kryteriów z definicji broni palnej z art. 7 u.b.a., bowiem stanowią przenośną broń lufową, która miota i została przeznaczona do miotania pocisków. Podstawowa dla kwalifikacji prawnej jest odpowiedź na pytanie, czy jest to wynikiem „działania materiału miotającego” (art. 7 ust. 1 u.b.a.), czego w ogóle nie przeanalizował sąd w glosowanym wyroku. Dokonując wykładni tego pojęcia, można sięgnąć do potocznego znaczenia i stwierdzić, że „miotać” oznacza to samo, co „rzucać daleko, ciskać”, a zatem materiałem miotającym może być cokolwiek, co spowoduje wyrzucenie przedmiotu miotanego daleko (Kulicki, Stępka 2012, 441) ${ }^{8}$. Odmiennie należy wskazać, że ustawodawca używa pojęcia materiału miotającego w znaczeniu nadanym mu w języku specjalistycznym tj. jako materiału miotającego wybuchowego, a nie w znaczeniu ogólnym (Rejmaniak 2018, 98). Podniesiono także, że użycie amunicji bocznego zapłonu kal. $6 \mathrm{~mm}$ wz. Flobert pozwala na zastosowanie jednego ładunku chemicznego, który jednocześnie pełni rolę materiału inicjującego i miotającego (Ćwik, Juszczyk 2013, 54-55). Powtórzyć zatem należy, że rewolwery tego typu nie wykorzystują materiału miotającego w rozumieniu normy obronnej ${ }^{9}$, bowiem wykorzystują mieszaninę na bazie trójnitrorezorcynianu ołowiu lub azydku ołowiu, lub piorunianu rtęci ${ }^{10}$ (zob. szerzej Bogusz et al. 2011, 56-57; Grzegorczyk, Wardak 2017b, 161-163). W języku potocznym używa się pojęcia prochu, a nie materiału miotającego. Także w języku stosowanym w środowisku łowieckim i w strzelectwie czarnoprochowym stosuje się pojęcie „naważka prochu”. Nieprawidłowa zatem jest wykładnia sięgająca do potocznego pojęcia materiału miotającego, bowiem ma ono charakter specjalistyczny. Wybuchowe materiały miotające i wybuchowe materiały inicjujące są to różne rodzaje materiałów wybuchowych, stąd też materiał inicjujący nie może być jednocześnie materiałem miotającym. Tym samym, skoro ustawodawca dokonał poniekąd modyfikacji definicji stworzonej przez normodawcę europejskiego ${ }^{11}$ i zmienił pojęcie materiału

${ }^{8}$ Mariusz Kulicki i Leszek Stępka podają przy tym przykład prądnicy (gaśnicy) strażackiej, wyrzucającej pod olbrzymim ciśnieniem strumień wody, do której wnętrza wprowadzimy kulkę z łożyska, która zostanie wyrzucona w wyniku działania materiału miotającego (wody) ma dużą odległość. Stwierdzają oni, że nie mamy do czynienia z bronią palną, która jednak spełnia desygnaty w ustawowej definicji broni palnej.

${ }^{9}$ Norma Obronna: Materiały Wybuchowe - Technologia NO-13-A007/A1:2012, która wskazuje że inicjującym materiałem wybuchowym jest związek chemiczny lub mieszanina zdolna do przemiany wybuchowej pod wpływem bodźca zewnętrznego, stosowana do wywołania tej przemiany w innych materiałach wybuchowych, zaś materiałem wybuchowym miotającym jest materiał wybuchowy, którego zasadniczą formą przemiany wybuchowej jest palenie, nieprzechodzące $\mathrm{w}$ detonację nawet pod wysokim ciśnieniem.

${ }^{10}$ Które są materiałami inicjującymi, a nie miotającymi.

${ }^{11}$ Dyrektywa Rady 91/477/ EWG z dnia 18 czerwca 1991 r. w sprawie kontroli nabywania i posiadania broni Dz. Urz. WE L 256 z dnia 13 września 1991 roku zmieniona dyrektywą Parlamentu Europejskiego i Rady 2008/51/WE z dnia 21 maja 2008 roku Dz. Urz. UE L 179.5 z dnia 8 lipca 2008 roku (zob. szerzej: Herzog 2011, 64; Stępka, Kwiatkowska-Wójcikiewicz 2013, 40-41) 
wybuchowego na materiał miotający, to nie chciał objęcia definicją wszystkich materiałów, które nadają się do miotania, a jedynie tych, które stanowią materiały miotające (zob. szerzej: Grzegorczyk, Wardak 2017b, 161-163) ${ }^{12}$. Z uwagi na brak użycia w przedmiotowych rewolwerach materiału miotającego nie spełniają one definicji broni palnej z art. 7 ust. 1 u.b.a.

Trudno jest także podzielić argument zawarty w glosowanym wyroku, powtarzany za literaturą (Rejmaniak 2017, 51; Rejmaniak 2018, 86-87), iż niebezpieczeństwo tkwi w samym określeniu „broń”. Odwołując się do języka potocznego zauważyć należy, że mamy do czynienia m.in. z „bronią zabawkową”. Także ustawodawca posługuje się np. pojęciem „broni pozbawionej cech użytkowych” (art. 9 ust. 2 u.b.a.), nadal nazywając te przedmioty, pozbawione cech konstytutywnych broni, bronią, z tym że pozbawioną cech użytkowych (odnośnie takiej broni zob. szerzej Starek, 2007, 149-158; Gorazdowski, Nowak 2004, 159-167; Gorazdowski 2011, 87-95). Jako broń określa się także broń historyczną, która często z uwagi na procesy destrukcyjne czasu i dekompletację części nie jest już w sposób faktyczny niebezpieczna. Przy kwalifikacji broni jako niebezpiecznego urządzenia, ustawodawcy $\mathrm{w}$ dawnym brzmieniu ustawy o broni i amunicji nie chodziło o jakiekolwiek niebezpieczeństwo. Pośród szeregu definicji w przypadku broni palnej (art. 7 ust. 1 u.b.a. sprzed nowelizacji z 2011 roku) oraz broni pneumatycznej (art. 8 u.b.a.) ustawodawca dodawał, iż ma to być „,niebezpieczne dla życia lub zdrowia urządzenie". W pozostałych rodzajach broni palnej, takich jak broń palna sygnałowa (art. 7 ust. 2 u.b.a.) oraz broń palna alarmowa (art. 7 ust. 3 u.b.a. $)^{13}$ ustawodawca nie zawarł takiego wymagania w treści definicji, chociaż niewątpliwie też są one niebezpieczne. W sposób oczywisty pewien ładunek niebezpieczeństwa tkwi również w broni palnej sygnałowej i alarmowej. Skoro zatem ustawodawca wskazywał, że te dwa rodzaje broni: palna i pneumatyczna, mają być niebezpieczne dla życia i zdrowia, to oznacza, że poziom tego niebezpieczeństwa ma być wyższy od niebezpieczeństwa, jakie za sobą niosą urządzenia także niebezpieczne tzn. broń palna sygnałowa i alarmowa. Tym samym skoro ustawodawca zrezygnował z przesłanki, iż ma to być „,niebezpieczne dla życia lub zdrowia urządzenie", to znaczy, że stwierdził, że nie wymaga do uznania za broń palną w rozumieniu ustawy o broni i amunicji wyższego poziomu niebezpieczeństwa, niż w przypadku broni palnej sygnałowej i alarmowej. Nie powinno być natomiast tak, że od broni palnej oczekujemy jedynie minimalnego poziomu niebezpieczeństwa dla życia lub zdrowia, tylko że to niebezpieczeństwo musi osiągnąć poziom znacznie wyższy od minimalnego.

oraz dyrektywą Parlamentu Europejskiego i Rady 2017/853 z dnia 17 maja 2017 roku Dz. Urz. UE L 137 z dnia 24 maja 2017 roku.

${ }^{12} \mathrm{~W}$ polskim tekście dyrektywy, w wersji nadanej dyrektywą z 2008 r., użyto pojęcia „materiału wybuchowego", zaś w wersji nadanej dyrektywą z 2017 r. użyto pojęcia „palnego materiału miotającego" przy tożsamym pojęciu w wersji angielskojęzycznej „,combustible propellant”.

${ }^{13}$ Odnośnie broni alarmowej zob. szerzej Wardak 2019, 465-483. 
Zgodzić się należy z sądem, który wyprowadził niebezpieczeństwo broni palnej z brzmienia art. $280 \S 2$ k.k., gdzie wskazano jako znamię kwalifikujące użycie broni palnej, noża lub innego podobnie niebezpiecznego przedmiotu (zob. podobnie Rejmaniak 2018, 87). Wykładnia systemowa wewnętrzna nakazuje przyjąć, że zarówno w rozumieniu art. 280 § 2 k.k., jak i art. 263 k.k. broń palna musi być niebezpieczna. Jednak potwierdza to tezę (Grzegorczyk, Wardak 2017a, 97), że definicja $\mathrm{z}$ art. 7 ust. 1 u.b.a. w brzmieniu po nowelizacji z art. 2011 roku jest niewystarczająca do przyjęcia, że mamy do czynienia z bronią palną w rozumieniu art. 263 i art. $280 \S 2$ k.k., które posługują się pojęciem broni i musimy szukać podstawowych kryteriów do wyróżnienia broni palnej poza definicją treściową zawartą w ustawie o broni i amunicji. Kryterium niebezpieczeństwa wraz z kryterium faktycznej zdolności miotania pocisków i rażenia celów na odległość, zawarte w danym brzmieniu art. 7 ust. 1 u.b.a., pozwalało przyjąć, że w ramach wykładni systemowej zewnętrznej art. 263 i art. $280 \S 2$ k.k. powinniśmy sięgać do definicji treściowej z art. 7 ust. 1 u.b.a. To pozwalało eliminować niezdolne do wystrzału tzw. destrukty oraz dekonstrukty broni, które przecież zostały w chwili ich wyprodukowania przeznaczone do „miotania”, tyle że z uwagi na np. korozję lub pozbawienie cech użytkowych bez spełnienia wymagań z ustawy o broni i amunicji taką zdolność utraciły (zob. Wardak 2017, 135). Obecnie brzmienie art. 7 ust. 1 u.b.a. nie umożliwia samodzielnej rekonstrukcji wszystkich istotnych znamion do przyjęcia odpowiedzialności karnej.

W wielu badaniach mierzono energię kinetyczną rewolwerów, określając ją: na $13,77 \mathrm{~J}^{14}$ (Kulicki, Stępka 2012, 446), 4,9-11 $\mathrm{J}^{15}$ i 3,5-4,8 $\mathrm{J}^{16}$ (Sprawozdanie z badań Wojskowego Instytutu Technicznego Uzbrojenia nr 31/2006 z dnia 13 listopada 2006 roku) w przedziale 5-10 $\mathbf{J}^{17}$ (Trnka, Golema 2017, 275-280). Badania (Bogusz et al. 2011, 38-41; Kulicki, Stępka 2012, 446; Kuliczkowski, Juszczyk 2015, 23-33) potwierdziły, że takie rewolwery mogą stanowić urządzenie niebezpieczne dla zdrowia, a nawet życia. Potwierdzają to także przypadki użycia takich rewolwerów w działalności przestępczej czy samobójstwach (np. Trnka, Golema 2017, 275-280). Niewątpliwie takie rewolwery niosą za sobą spory ładunek niebezpieczeństwa, nie są to nieszkodliwe zabawki, niemogące wyrządzić krzywdy. Natomiast trzeba zauważyć, że ustawodawca dopuszcza bez pozwolenia szereg niebezpiecznych dla życia i zdrowia urządzeń np. urządzenia pneumatyczne (o energii kinetycznej pocisku poniżej 17J - art. 8 ust. 1 a contrario u.b.a. i jako takich nie stanowiących broni pneumatycznej, a co za tym idzie w ogóle broni), łuki (reglamentacji podlegają wyłącznie kusze - art. 4 ust. 1 pkt 4 lit b u.b.a.), a także broń palną rozdzielnego ładowania, wytworzoną przed rokiem 1885 oraz repliki tej broni (art. 11 pkt 10 u.b.a. - zob. szerzej Chałupka 2018, 80-90), która

\footnotetext{
${ }^{14}$ Badano Zoraki K-45.

${ }^{15}$ Badano Keseru K-10.

${ }^{16}$ Badano Keseru K-56.

${ }^{17}$ Badano Keseru K-56.
} 
cechuje się bardzo dużą siłą rażenia, podobną do współczesnej broni strzeleckiej, wielokrotnie większą od przedmiotowych rewolwerów. Energia kinetyczna osiągana przez pociski wystrzeliwane z przedmiotowych rewolwerów jest zbliżona do dopuszczonych do swobodnego obrotu popularnych wiatrówek, co do których także szereg badań potwierdza ich niebezpieczeństwo (np. Woźniak, Pohl 2003, 347-355; Stępniewski, Mówiński, Sokół 2006, 223-227; Woźniak et al. 2009, 326329; Smędra-Kaźmirska et. al. 2010; Kędzierski, Meissner, Berent 2010, 132-136; Smędra-Kaźmirska et. al. 2011, 102-106). Urządzenia pneumatyczne o energii kinetycznej pocisku poniżej 17J potrafią spowodować znaczne obrażenia, a nawet śmierć ${ }^{18}$. W przypadku takich urządzeń pneumatycznych ustawodawca nie zdecydował się jednak na objęcie ich reglamentacją wynikającą z ustawy o broni i amunicji i są one poza zakresem kryminalizacji z art. 263 k.k., a ich użycie nie mieści się w znamieniu kwalifikującym z art. 280 § 2 k.k. W sprawie objętej glosowanym orzeczeniem sąd uznał natomiast, że użycie rewolweru niebezpiecznego w podobnym stopniu jak urządzenia pneumatycznego, nie objętego reglamentacją ustawą o broni i amunicji, niesie za sobą przyjęcie typu kwalifikowanego $\mathrm{z}$ art. $280 \S 2$ k.k. Rewolwer ten, z uwagi na brak użycia materiału miotającego, nie stanowi przy tym broni palnej w rozumieniu art. 7 u.b.a. Stąd też nie można uznać kwalifikacji dokonanej przez sąd, który przyjął użycie rewolweru Keseru jako wyczerpującej znamię typu kwalifikowanego z art. $280 \S 2$ k.k. tj. broni palnej, noża lub innego podobnie niebezpiecznego przedmiotu za prawidłową.

W glosowanym wyroku sąd stwierdził, że rewolwery, takie jak poddane ocenie w przedmiotowej sprawie, stanowią ,urządzenie” i mogą powodować niebezpieczeństwo zbliżone do powodowanego przez broń gazową, sygnałową, czy alarmową, których normalne użycie nie powinno stanowić zagrożenia dla życia lub zdrowia, a de lege lata są one zaliczane do kategorii broni palnej (por. badania przeprowadzone Kuliczkowski, Juszczyk 2015, 21-34). W realiach dowodowych rozpoznawanej sprawy nie była przedmiotowa broń nic nieznaczącym „straszakiem - atrapą”, czy „niewinną - rekreacyjną” wiatrówką. To zostało ewidentnie i w zgodzie z rzeczywistym przebiegiem kolejnych czynów wykluczone, a przede wszystkim ujęte w ramach kompleksowej i właściwej kwalifikacji prawnej jako znamię kwalifikujące typ przestępstwa rozboju. Nie zachodziła sytuacja niejasności, czy niepełności opinii biegłego, który kategorycznie i konsekwentnie wyraził swoje stanowisko oparte na niewątpliwych kompetencjach merytorycznych. Należy przy tym zauważyć, że z opisu stanu faktycznego w glosowanym wyroku sprawca posługiwał się rewolwerem Zoraki K-55, tzn. strzelającym śrutem ołowianym kal. $5,5 \mathrm{~mm}$, podczas gdy w publikacji, na którą powołał się sąd, analizowano rewolwery Zoraki/Keseru K-10, strzelające kulami „gumowymi” kal. 10 mm, nie zaś strzelające śrutem kal. 4,5 czy 5,5 mm. Sąd powołał się przy tym na te publikacje

${ }^{18} \mathrm{~W}$ badaniach przy tym stwierdzono bardzo duży wpływ rodzaju pocisku na możliwość wywołania obrażeń. 
(pośrednio za przypisem w publikacji Rafała Rejmaniaka ${ }^{19}$ ) jako wsparcie dokonanej przez siebie kwalifikacji. Niebezpieczeństwo użycia rewolwerów strzelających śrutem kal. 4,5 czy 5,5 mm jest takie samo, jak ,,rekreacyjnych” wiatrówek ${ }^{20}$. Zauważyć przy tym należy, że sama kontrola opinii pod względem jej jasności i pełności, tzn. kontrola z art. 201 ustawy z dnia 6 czerwca 1997 r. Kodeks postępowania karnego (t.j. Dz.U. z 2020 r., poz. 30 ze zm., dalej k.p.k.) nie może stanowić jedynej kontroli opinii biegłego, ale powinna być badana pod względem wskazań wiedzy (art. 7 k.p.k. - zob. szerzej Grzegorczyk, Wardak 2014, 209-217), co wymaga szerszego spojrzenia w dorobek nauki. W glosowanym wyroku sąd powołał się odnośnie charakteru prawnego rewolweru Zoraki także na postanowienie Sądu Najwyższego z dnia 4 listopada 2015 r., III KK 122/15²1, które dotyczy rewolweru Zoraki K6L, zasadniczo odmiennego z uwagi na fakt strzelania nabojami hukowymi $6 \mathrm{~mm}$ long, zawierającymi materiał miotający, a nie jedynie inicjujący oraz bez możliwości strzelania pociskami w postaci śrutu ${ }^{22}$.

De lege ferenda ponownie należy postulować nowelizację przepisu art. 7 ust. 1 u.b.a., która mogłaby polegać na przywróceniu poprzedniego brzmienia tego przepisu sprzed nowelizacji, przy czym należałoby rozważyć wprowadzenie w niej kilku zmian. Po pierwsze, należy wprowadzić kryterium energetyczne wzorem broni pneumatycznej z art. 8 u.b.a. ${ }^{23}$, które precyzowałoby sytuacje reglamentowania takich urządzeń i zwalniałoby z konieczności uzyskiwania pozwolenia na urządzenia strzelające $\mathrm{z}$ niską energią. Po drugie, należałoby zamienić określenie materiału

${ }^{19}$ Sąd odwołał się przy tym tylko do cyt.: „ostatniego opracowania poświęconego tej 'militarnej', ale i prawnej problematyce” tj. publikacji R. Rejmaniaka (2018, 78-103), co samo w sobie zasługuje na aprobatę, szkoda tylko, że nie sięgnął chociażby do publikacji, z którą R. Rejmaniak wprost polemizuje (Grzegorczyk, Wardak 2017a, 85-99), czy też do innych publikacji, które bardzo krytycznie odniosły się do nowelizacji ustawy o broni i amunicji (np. Herzog 2011, 66-68; Kasprzak 2013a, 61-70; Stępka, Kwiatkowska-Wójcikiewicz 2013, 37-52), czy też publikacji, które wprost analizują prawnie przedmiotowe rewolwery, uznając je za broń palną (Ćwik, Juszczyk 2013, 56; Borusiński, Juszczyk 2018, 11; Kulicki, Stępka 2012, 443-444; Kasprzak, 2013b, 75-76) lub też nie (Bogusz et al. 2011, 56-57; Grzegorczyk, Wardak 2017b, 161-163).

${ }^{20}$ Które, jak wcześniej wskazano, nie są bynajmniej niegroźnymi, „niewinnymi” urządzeniami. Mają one podobną energię kinetyczną pocisków opuszczających lufę, stosuje się też w nich identyczne pociski. Od urządzeń pneumatycznych różni przedmiotowe rewolwery sposób sprężania gazów, poprzez reakcję materiału inicjującego, której towarzyszy wystrzał, nie zaś gaz z zasobnika, bądź sprężony mechanicznie, jak w „wiatrówkach” oraz towarzyszący im huk wystrzału.

${ }^{21}$ Krakowskie Zeszyty Saqdowe 2017: 1, poz. 25; Lex 1941895; Legalis 1370965.

${ }^{22}$ Uznany za broń palną art. 7 ust. 1 u.b.a. prawdopodobnie z uwagi na ewentualną możliwość użycia nabojów gazowych $6 \mathrm{~mm}$ long - opis stanu faktycznego nie pozwala na rekonstrukcję opinii i dokonanej kwalifikacji.

${ }^{23}$ Do rozważenia natomiast jest konkretna wartość energii kinetycznej, bowiem jak wskazuje Mariusz Kulicki już wartość powyżej 7,5 J może być wartością niebezpieczną, z uwagi na co np. w Niemczech zabawki pneumatyczne nie objęte reglamentacją są do 7,5 J (zob. Kulicki, Kwiatkowska-Darul, Stępka 2002, 35; Kulicki, Stępka, Stucki 2003, 46-52). 
miotającego na materiał wybuchowy, bądź też dookreślenie, iż chodzi o wybuchowy materiał miotający i inicjujący. Przeprowadzenie takich zmian, w stosunku do definicji sprzed nowelizacji pozwoliłoby na wyraźne wyeliminowanie urządzeń takich rewolwerów jak Zoraki, w których wystrzał odbywa się przez reakcję materiału inicjującego (niebędącego materiałem miotającym), a z drugiej strony pozwoliłoby na legalny obrót urządzeniami, w których dochodzi do spalania się materiału miotającego, ale których energia kinetyczna jest na tym samym poziomie, co urządzeń pneumatycznych, niepodlegających reglamentacji (Grzegorczyk, Wardak 2017a, 98; zob. także m.in. Stępka, Kwiatkowska-Wójcikiewicz 2013, 40²4).

\section{BIBLIOGRAFIA}

Bogusz, Zbigniew. Piotr Grzegorczyk. Wojciech Thiel. Zbigniew Wardak. 2011. „Kryminalistyczna problematyka broni akustyczno-pneumatycznej”. W Co nowego w kryminalistyce - przeglad zagadnień z zakresu zwalczania przestępczości. Red. Mieczysław Goc, Ewa Gruza, Tadeusz Tomaszewski. 33-50. Warszawa: Stowarzyszenie Absolwentów Wydziału Prawa Uniwersytetu Warszawskiego.

Borusiński, Michał. Henryk Juszczyk. 2018. „Wpływ opinii biegłych na sprzedaż broni na terenie Polski”. Problemy Kryminalistyki 299: 10-13.

Chałupka, Katarzyna. 2018. „Broń palna rozdzielnego ładowania wytworzona przed rokiem 1885”. Prokuratura i Prawo 3: 80-90.

Ćwik, Krzysztof. Henryk Juszczyk. 2013. „Kwalifikacja prawna rewolwerów Keseru K-10 i Zoraki K-10 pod kątem legalności ich posiadania na terenie Polski”. Problemy Kryminalistyki 279: 53-55.

Gorazdowski, Krzysztof. 2011. „Pozbawianie cech użytkowych broni palnej”. W Co nowego w kryminalistyce - przegląd zagadnień z zakresu zwalczania przestępczości. Red. Mieczysław Goc, Ewa Gruza, Tadeusz Tomaszewski. 87-95. Warszawa: Stowarzyszenie Absolwentów Wydziału Prawa Uniwersytetu Warszawskiego.

Gorazdowski, Krzysztof. Andrzej Nowak. 2004. „Wątpliwości wokół pojęcia broni palnej pozbawionej cech użytkowych". Prokuratura i Prawo 6: 159-167.

Grzegorczyk, Piotr. Zbigniew Wardak. 2014. „Wskazania wiedzy jako podstawa niezbędna orzeczniczo". W Dowodzenie w procesach karnych. Red. Ryszard Sztychmiler, Jerzy Kasprzak, Justyna Krzywkowska. 209-217. Olsztyn: Wydawnictwo Uniwersytetu Warmińsko-Mazurskiego.

Grzegorczyk, Piotr. Zbigniew Wardak. 2017a. „Pojęcie broni palnej w prawie karnym”. Prokuratura i Prawo 10: 85-99.

Grzegorczyk, Piotr. Zbigniew Wardak. 2017b. „Glosa do wyroku Sądu Najwyższego z dnia 30 czerwca 2016 r., sygn. akt II KK 47/16”. Studia Prawnoustrojowe 36: 157-164.

Herzog, Aleksander. 2011. „Ustawa o broni i amunicji po nowelizacji”. Prokuratura i Prawo 10: 64-82.

Kasprzak, Jerzy. 2010. „Istotne części broni - czyli istotne problemy z interpretacją prawa”. W Co nowego w kryminalistyce - przegląd zagadnień z zakresu zwalczania przestępczości. 121-128. Red. Mieczysław Goc, Ewa Gruza, Tadeusz Tomaszewski. Warszawa: Stowarzyszenie Absolwentów Wydziału Prawa Uniwersytetu Warszawskiego.

${ }^{24}$ Którzy zaproponowali, że bronią palną jest niebezpieczne narzędzie, które ze względu na budowę oraz przewidziany przez wytwórcę lub użytkownika sposób wykorzystania gazów powstających ze spalania materiału miotającego ma zdolność wystrzelenia pocisku, z energią zdolną spowodować śmierć lub ciężkie uszkodzenia ciała człowieka, nie mniejszą jednak niż $17 \mathrm{~J}$. 
Kasprzak, Jerzy. 2013a. „W trosce o poprawną definicję broni palnej”. Przegląd Policyjny 2: 61-70. Kasprzak, Jerzy. 2013b. „Niebezpieczne zabawki czy broń palna?” W Broń - problematyka prawna i kryminalistyczna. Red. Violetta Kwiatkowska-Wójcikiewicz, Leszek Stępka. 61-76. Toruń: Wydawnictwo Naukowe Uniwersytetu Mikołaja Kopernika.

Kędzierski, Maciej. Ewa Meissner. Jarosław Berent. 2010. „Śmiertelny postrzał z broni pneumatycznej”. Archiwum Medycyny Sądowej i Kryminologii 60(1): 132-136.

Kulicki, Mariusz. Leszek Stępka. 2009. „Typy broni palnej i ich istotne części w kontekście legalnej definicji broni palnej". W Kryminalistyka i inne nauki pomostowe w postepowaniu karnym. Red. Jerzy Kasprzak, Bronisław Młodziejowski. 509-517. Olsztyn: Print Group,

Kulicki, Mariusz. Leszek Stępka. 2012. „Prawnokarne i kryminalistyczne pojęcie broni strzeleckiej w świetle zmian przepisów ustawy o broni i amunicji”. W Nauki penalne wobec szybkich przemian socjokulturowych. Księga jubileuszowa Profesora Mariana Filara. Red. Andrzej Adamski, Janusz Bojarski, Piotr Chrzczonowicz, Michał Leciak. 435-449. Warszawa: Wydawnictwo Adam Marszałek.

Kulicki, Mariusz. Violetta Kwiatkowska-Darul. Leszek Stępka. 2002. "Przyczynek do dyskusji nad definicją broni palnej, gazowej i pneumatycznej”. Przeglad Policyjny 3-4: 28-37.

Kulicki, Mariusz. Leszek Stępka. Dariusz Stucki. 2003. Kryminalistyczno-prawna problematyka broni strzeleckiej. Komentarz do przepisów o broni i amunicji. Kraków: Zakamycze.

Kuliczkowski, Maciej. Henryk Juszczyk. 2015. „Uszkodzenia spowodowane pociskami wystrzeliwanymi z rewolwerów ZORAKI R1 mod. K-10 kal. 6 mm/10 mm”. Problemy Kryminalistyki 290: 21-34.

Rejmaniak, Rafał. 2017. Wyrabianie, handel i posiadanie broni palnej oraz amunicji w Polsce. Aspekty karnoprawne i kryminologiczne. Torun: Wydawnictwo Adam Marszałek.

Rejmaniak, Rafał. 2018. „Pojęcie broni palnej”. Prokuratura i Prawo 4: 78-103.

Smędra-Kaźmirska, Anna. Maciej Bardzo. Maciej Kędzierski. Stefan Szram. Jarosław Berent. 2010. „Doświadczalny efekt postrzału pociskami kalibru 4,5 mm wystrzeliwanymi z karabinka pneumatycznego Norica Dragon i pistoletu pneumatycznego Walther PPK/S". Archiwum Medycyny Sądowej i Kryminologii 60(2): 77-82.

Smędra-Kaźmirska, Anna. Maciej Bardzo. Maciej Kędzierski. Stefan Szram. Jarosław Berent. 2011. „Głębokość penetracji pocisków, wystrzelonych z urządzenia pneumatycznego o energii kinetycznej poniżej $17 \mathrm{~J}$, w $20 \%$ blokach żelatynowych w korelacji ze stwierdzonymi sekcyjnie obrażeniami ciała 9-letniego chłopca". Archiwum Medycyny Sądowej i Kryminologii 61(2): 102-106.

Starek, Wiesław. 2007. „Broń palna pozbawiona cech użytkowych”. Problemy Techniki Uzbrojenia 104: 149-158.

Stępka, Leszek. Violetta Kwiatkowska-Wójcikiewicz. 2013. „Istota broni palnej”. W Broń: problematyka prawna i kryminalistyczna. Red. Violetta Kwiatkowska-Wójcikiewicz, Leszek Stępka. 37-52. Toruń: Wydawnictwo Naukowe Uniwersytetu Mikołaja Kopernika.

Stępniewski, Wojciech. Grzegorz Mówiński. Wojciech Sokół. 2006. „Doświadczalny efekt biologiczny postrzału pociskami kalibru $4.5 \mathrm{~mm}$ BB z pistoletu pneumatycznego A-101". Archiwum Medycyny Sadowej i Kryminologii 56(4): 223-227.

Trnka, Jakub. Wojciech P. Golema. 2017. „Przypadek samobójczego postrzału głowy z rewolweru hukowo-kinetycznego typu 'Keseru' jako przykład niebezpieczeństw związanych z używaniem replik broni dostępnych bez zezwolenia". Archiwum Medycyny Sądowej i Kryminologii 67(4): 275-280.

Wardak, Zbigniew. 2017. „Glosa do wyroku Sądu Najwyższego z dnia 21 stycznia 2015 r., sygn. akt IV KK 343/14 (istotna część broni palnej jako broń palna)". Wojskowy Przeglad Prawniczy 4: $126-137$. 
Wardak, Zbigniew. 2019. „Broń palna alarmowa - problematyka prawna i kryminalistyczna”. Studia Prawnoustrojowe 46: 465-483.

Woźniak, Krzysztof. Jerzy Pohl. 2003. „Samobójcze postrzały z broni śrutowej po wprowadzeniu lufy do ust a ryzyko błędnej oceny na miejscu ujawnienia zwłok". Archiwum Medycyny Sadowej i Kryminologii 53(4): 347-355.

Woźniak, Krzysztof. Elżbieta Nowaczek-Dziocha. Artur Moskała. Andrzej Urbanik. Jerzy Pohl. 2009. „Rekonstrukcja kanału postrzału z wiatrówki w zakresie szyi - opis przypadku”. Archiwum Medycyny Sądowej i Kryminologii 59(4): 326-329.

\title{
Akty prawne
}

Ustawa z dnia 6 czerwca 1997 r. Kodeks karny (t.j. Dz.U. z 2020 r. poz. 1444 ze zm.).

Ustawa z dnia 6 czerwca 1997 r. Kodeks postępowania karnego (t.j. Dz.U. z 2020 r. poz. 30 ze zm.). Ustawa z dnia 21 maja 1999 r. o broni i amunicji (t.j. Dz.U. z 2020 r. poz. 955 ze zm.).

\section{Orzecznictwo}

Postanowienie Sądu Najwyższego z dnia 4 listopada 2015 r., III KK 122/15, Krakowskie Zeszyty Sadowe 2017: 1, poz. 25; Lex 1941895; Legalis 1370965.

Wyrok Sądu Najwyższego z dnia 30 czerwca 2016 r., sygn. akt II KK 47/16, OSNPK 2016: 10, poz. 5; Krakowskie Zeszyty Sadowe 2016: 10, poz. 17; Prokuratura i Prawo - dodatek Orzecznictwo 2016: 10, poz. 5; Lex 2077541; Legalis 1482667.

\section{Piotr Grzegorczyk, Zbigniew Wardak}

\section{COMMENTARY ON THE SENTENCE OF THE APPEAL COURT - JUNI 14, 2018, REF. NO. II AKA 111/18}

\begin{abstract}
The article is a critical comment to the judgment of the Lódź Court of Appeal of 14 June 2018, II AKa 111/18. The authors, noticing the complex issues of firearms both under criminal law and on the level of criminal doctrine, made an attempt to specify the premises for the qualification of firearms and firing devices such as the Zoraki revolver. Undoubtedly, these revolvers meet part of the criteria of the definition of firearms from art. 7 u.b.a., because they are a portable barrel weapon, which launches projectiles and was designed to shoot missiles, but taking as a starting point the interpretation of this article, it is still necessary to determine whether the substance used in the firing mechanism is a "propellant material", which the court did not do. The authors specify this term by excluding the use of the colloquial understanding of this wording and by referring to the specialist language specified in the defense standard, which contains definitions of explosives. The comment also touches the issue of the "danger" premise of firearms and interpretation problems based on the content and system interpretation of art. 7 item 1 of u.b.a., art. 263 and art. $280 \S 2$ of the Penal Code. The authors argument, that the current wording of art. 7 item 1 u.b.a. does not allow independent, full reconstruction of all significant features for criminal liability. This comment also expresses de lege ferenda postulates regarding the change in the definition of art. 7 item 1 u.b.a. and introducing the energy criteria for firearms and specifying the premise of "propellant material" by stating that it is explosive or propellant or initiating material, which would allow for a precise assessment as to the legal qualification of penalized behavior.
\end{abstract}

Keywords: firearm, Keseru, Zoraki, danger permise, definition of firearm, explosive material, propellent material, initiating material, criminal liability. 